\title{
Low levels of fine particulate matter increase vascular damage and reduce pulmonary function in young healthy adults
}

Lauren H. Wyatt ${ }^{*}$, Robert B. Devlin, Ana G. Rappold, Martin W. Case and David Diaz-Sanchez

\begin{abstract}
Background: Fine particulate matter $\left(\mathrm{PM}_{2.5}\right)$ related mild inflammation, altered autonomic control of cardiovascular function, and changes to cell function have been observed in controlled human exposure studies.

Methods: To measure the systemic and cardiopulmonary impacts of low-level PM exposure, we exposed 20 healthy, young volunteers to $\mathrm{PM}_{2.5}$, in the form of concentrated ambient particles (mean: $37.8 \mu \mathrm{g} / \mathrm{m}^{3}, \mathrm{SD} 6.5$ ), and filtered air (mean: $2.1 \mathrm{\mu g} / \mathrm{m}^{3}$, SD 2.6). In this double-blind, crossover study the exposure order was randomized. During the $4 \mathrm{~h}$ exposure, volunteers (7 females and $13 \mathrm{males}$ ) underwent light intensity exercise to regulate ventilation rate. We measured pulmonary, cardiac, and hematologic end points before exposure, $1 \mathrm{~h}$ after exposure, and again $20 \mathrm{~h}$ after exposure.

Results: Low-level $\mathrm{PM}_{2.5}$ resulted in both pulmonary and extra-pulmonary changes characterized by alterations in systematic inflammation markers, cardiac repolarization, and decreased pulmonary function. A mean increase in $\mathrm{PM}_{2.5}$ concentration $\left(37.8 \mu \mathrm{g} / \mathrm{m}^{3}\right)$ significantly increased serum amyloid A (SAA), C-reactive protein (CRP), soluble intercellular adhesion molecule-1 (sICAM-1), and soluble vascular cell adhesion molecule-1 (sVCAM-1), $1 \mathrm{~h}$ after exposure by $8.7,9.1,10.7$, and $6.6 \%$, respectively, relative to the filtered air control. SAA remained significantly elevated (34.6\%) $20 \mathrm{~h}$ after $\mathrm{PM}_{2.5}$ exposure which was accompanied by a $5.7 \%$ decrease in percent neutrophils. Decreased pulmonary function was observed $1 \mathrm{~h}$ after exposure through a 0.8 and $1.2 \%$ decrease in forced expiratory volume in $1 \mathrm{~s}\left(\mathrm{FEV}_{1}\right)$ and $\mathrm{FEV}_{1} /$ forced vital capacity $\left(\mathrm{FEV}_{1} / \mathrm{FVC}\right)$ respectively. Additionally, sex specific changes were observed in repolarization outcomes following PM 2.5 exposure. In males, P-wave and QRS complex were increased by 15.4 and $5.4 \% 1 \mathrm{~h}$ after exposure.
\end{abstract}

Conclusions: This study is the first controlled human exposure study to demonstrate biological effects in response to exposure to concentrated ambient air $\mathrm{PM}_{2.5}$ particles at levels near the $\mathrm{PM}_{2.5}$ US NAAQS standard.

Clinical trial registration information: clinicaltrials.gov; Identifier: NCT03232086. The study was registered retrospectively on July 25, 2017, prior to final data collection on October 25, 2017 and data analysis.

Keywords: Systemic inflammatory effect, Healthy human volunteers, Particulate matter air pollution, Controlled exposure

\footnotetext{
* Correspondence: Wyatt.lauren@epa.gov

Public Health and Integrated Toxicology Division, Human Studies Facility, United States Environmental Protection Agency (USEPA), Research Triangle Park, 104 Mason Farm Rd, Chapel Hill, NC 27514, USA
}

(c) The Author(s). 2020 Open Access This article is licensed under a Creative Commons Attribution 4.0 International License, which permits use, sharing, adaptation, distribution and reproduction in any medium or format, as long as you give appropriate credit to the original author(s) and the source, provide a link to the Creative Commons licence, and indicate if changes were made. The images or other third party material in this article are included in the article's Creative Commons licence, unless indicated otherwise in a credit line to the material. If material is not included in the article's Creative Commons licence and your intended use is not permitted by statutory regulation or exceeds the permitted use, you will need to obtain permission directly from the copyright holder. To view a copy of this licence, visit http://creativecommons.org/licenses/by/4.0/ The Creative Commons Public Domain Dedication waiver (http://creativecommons.org/publicdomain/zero/1.0/) applies to the data made available in this article, unless otherwise stated in a credit line to the data. 


\section{Introduction}

Exposure to particulate matter (PM) air pollution is associated with elevated rates of mortality and morbidity [1-4]. In 2015, it was estimated that over 4.2 million premature deaths and over 103 million years of healthy life lost were attributable to ambient particulate matter pollution, making it one of the top global health risk factors [5]. Similarly, the American Heart Association has concluded that "Exposure to $\mathrm{PM}<2.5 \mu \mathrm{m}$ in diameter $\left(\mathrm{PM}_{2.5}\right)$ over a few hours to weeks can trigger cardiovascular disease-related mortality and nonfatal events" [1]. Associations with short-term $\mathrm{PM}_{2.5}$ exposure have been demonstrated in more than 100 time-series and casecrossover analyses and include risk of a myocardial infarction (MI), aggravated asthma, changes in acute respiratory response, and increased risk for hospitalization and mortality [1, 6-12].

Findings from these epidemiological studies are strengthened by data from controlled human exposure studies where subjects are exposed on separate occasions to clean air or known $\mathrm{PM}_{2.5}$ concentrations and pollutant-induced changes in cardiopulmonary biomarkers are assessed post-exposure. Controlled human exposure studies have shown that healthy volunteers exposed to $\mathrm{PM}_{2.5}$ primarily exhibit mild pulmonary inflammation, altered autonomic control of heart function, altered endothelial cell function, vascular inflammation, and changes in blood factors associated with coagulation and fibrinolysis, when compared to clean air exposures [11]. Controlled exposure studies provide biological plausibility to epidemiological studies by delineating pathophysiological changes following $\mathrm{PM}_{2.5}$ exposure in relevant biological pathways that can explain the epidemiological findings. Unlike epidemiological studies, controlled exposure studies can assess the direct causal effect of $\mathrm{PM}_{2.5}$ exposure by comparing an individual's response following clean air and $\mathrm{PM}_{2.5}$ exposures. $\mathrm{PM}_{2.5}$ related effects observed in these exposure studies do not need to be disassociated from the impacts of other pollutants and confounders, providing more direct evidence of the potential of these particles to exert pulmonary and extra-pulmonary effects [13-16]. However, nearly all these studies have been conducted at realistic but high levels of $\mathrm{PM}_{2.5}$ (typically above $100 \mu \mathrm{g} / \mathrm{m}^{3}$ ). This has led to concern that the biological pathways changed at these elevated concentrations may not be relevant at lower concentrations.

In this study, we measured the cardiopulmonary changes in healthy young volunteers exposed acutely to levels of $\mathrm{PM}_{2.5}$ near the 24-h US National Ambient Air Quality Standard (NAAQS) for $\mathrm{PM}_{2.5}$ of $35 \mu \mathrm{g} / \mathrm{m}^{3}$. Subjects underwent intermittent exercise to regulate exposure, which may simulate light intensity exercise outside. In panel studies involving physical activity, air pollution was associated with reductions in cardiorespiratory biomarkers [12, 17, 18]. We examined lung function, systemic changes in the blood, and the electrophysiology following 4-h $\mathrm{PM}_{2.5}$ exposures. We hypothesized that the same pathways activated by elevated levels of $\mathrm{PM}_{2.5}$ would also be activated at ambient levels found in many urban areas.

\section{Methods}

\section{Study population}

Healthy adult subjects, aged 18-35 years, were recruited from the central North Carolina area between February and October 2017. Inclusion criteria included the ability to complete the exercise regimen without reaching $80 \%$ of the predicted maximal heart rate [19] while maintaining an oxygen saturation of $\geq 92 \%$, a normal baseline electrocardiography (ECG), and normal lung function (FVC and $\mathrm{FEV}_{1} \geq 80 \%$ of that predicted for sex, ethnicity, age, and height) [20]. Subjects were excluded if they were smokers (frequent smokers and those with a history of $>5$ pack years) or had acute or chronic illnesses such as asthma, diabetes, cancer, or any autoimmune abnormalities. Prior to enrollment, subjects were informed of the study procedures and risks and informed consent was obtained. The study protocol and consent forms were approved by the University of North Carolina at Chapel Hill Institutional Review Board and the US Environmental Protection Agency Human Subjects Research Review Office. The study has been registered as a clinical trial (ClinicalTrials.gov \# NCT03232086). The study enrolled 21 subjects; however, the data for 20 subjects are presented as one subject did not complete both exposures.

\section{Study design and exposure to $\mathrm{PM}_{2.5}$}

This was a randomized, double-blind, crossover study. Subjects received two 4-h exposures, one to clean air (control exposure) and one to concentrated $\mathrm{PM}_{2.5}$, with intermittent exercise, on two separate occasions separated on average by 38 days, to limit cross exposure effects, at the EPA Human Studies Facility. The airshed around the facility is urban and primarily driven by mobile sources (e.g. traffic). The exposure order was randomized by subject. Subjects were asked to refrain from consuming alcohol and caffeine $24 \mathrm{~h}$ prior to all exposures. The 4-h exposure was administered as a 2-h exposure, followed by a 30-min period to record blood pressure, perform a symptom questionnaire, and have a restroom break, then a second 2-h exposure. During exposures subjects alternated between cycles consisting of $15 \mathrm{~min}$ of exercise on a stationary recumbent bicycle and 15 min of rest. Tension on the exercise bike was adjusted for subjects to achieve the target ventilation rate of $20 \mathrm{~L} /$ $\mathrm{min} / \mathrm{m}^{2}$ body surface area, which would enable subjects 
to receive approximately the same dose of $\mathrm{PM}_{2.5}$ [21]. Spirometry, venipuncture, and Holter monitor measures of heart rate variability and repolarization were performed immediately prior to exposure (pre-exposure), 1 $\mathrm{h}$ post exposure (post-exposure), and $20 \mathrm{~h}$ post exposure (follow-up exposure) as previously described [22-24].

Exposure to filtered air and concentrated $\mathrm{PM}_{2.5}$ particles was conducted as described previously [22] by concentrating ambient air from around the Human Studies Facility with a 2-stage aerosol Harvard concentrator. The target exposure was $35 \mu \mathrm{g} / \mathrm{m}^{3}$, which corresponds to the $24 \mathrm{~h}$ NAAQS. Due to variation of ambient air quality over the course of ambient air quality over the 4 $\mathrm{h}$ and day to day, the concentrator was able to achieve an average concentration of $37.8 \mu \mathrm{g} / \mathrm{m}^{3}$ (SD 6.5). Table S1 shows the actual exposure concentrations for each subject. All exposures began within $30 \mathrm{~min}$ of $0930 \mathrm{~h}$ to control for diurnal variations in physiologic response.

\section{Exposure methodology regarding concentrated $\mathrm{PM}_{2.5}$ exposure}

Concentrated particles were generated by drawing ambient air from above the roof of the US Human Studies Facility (Chapel Hill, NC) and passing the air through a two-stage aerosol concentrator which produces up to a 30-fold increase in particle number and mass. Particles larger than about $2.5 \mu \mathrm{m}$ were excluded by a sizeselective inlet from entering the concentrator at the rooftop intake. During the particle concentrating process, ambient air pollution gases were diluted. Air temperature and humidity were monitored and maintained to ensure proper operation of the concentrator. The chamber exposure atmosphere averaged $40 \% \pm 10 \%$ relative humidity and approximately $22 \pm 2{ }^{\circ} \mathrm{C}$. The concentration of particles delivered to the chamber varies depending on the levels of naturally occurring particles in the Chapel Hill, NC air as well as meteorological and other factors. Therefore, particle concentrations in the chamber were monitored continually and the particle concentration diluted with clean air as needed to achieve the target concentration range of $35-50 \mu \mathrm{g} / \mathrm{m} 3$. Exposures were monitored in real time through instrumentation and the actual concentration of concentrated particles delivered was determined retrospectively by filter gravimetry.

\section{End point measurements Spirometry}

Pulmonary function was measured with a SensorMedics Vmax system (VIASYS, Conshohocken, PA). Forced vital capacity (FVC), $\mathrm{FEV}_{1}$, mid-expiratory flow rate (FEF 25$75 \%$ ), and peak expiratory flow (PEF) were measured pre-exposure, post-exposure, and during follow-up as described earlier [21, 25].

\section{Cellular and soluble blood components}

Venous blood was collected pre-exposure, postexposure, and during follow-up for each exposure. Basic blood chemistry and complete blood count with differential counts by cell type were measured by LabCorp (Burlington, NC) on the day the blood was drawn. Plasma and serum were also frozen at $-80^{\circ} \mathrm{C}$ for later analysis. Basic blood chemistry endpoints measured included cholesterol $(\mathrm{mg} / \mathrm{dL})$, triglycerides $(\mathrm{mg} / \mathrm{dL})$, lowdensity lipoproteins (LDL, $\mathrm{mg} / \mathrm{dL}$ ), very low-density lipoproteins (VLDL, $\mathrm{mg} / \mathrm{dL}$ ), and high-density lipoproteins (HDL $\mathrm{mg} / \mathrm{dL}$ ). Complete blood count included white blood cells (WBC, $10^{3} / \mu \mathrm{L}$ ), red blood cells (RBC, $10^{3}$ / $\mu \mathrm{L})$, platelets $\left(10^{3} / \mu \mathrm{L}\right)$, hemoglobin $(\mathrm{g} / \mathrm{dL})$, neutrophils (\%), lymphocytes (\%), and hematocrit (\%). Analyses were performed on the Meso Scale Discovery multiplex assay system (Meso Scale Diagnostics, LLC, Rockville, MD) in two separate kits: one for pro-inflammatory mediators: interleukin 1-beta (IL-1 $\beta$ ), IL-6, IL-8, and tumor necrosis factor-alpha (TNF- $\alpha$ ) and another for vascular injury: CRP, serum amyloid A (SAA), soluble intercellular adhesion molecule-1 (sICAM-1), soluble vascular cell adhesion molecule-1 (sVCAM-1). All other assays (d-dimer, tissue plasminogen activator (tPA), von Willebrand Factor (vWF) and plasminogen activator inhibitor 1 (PAI1)) were established using the Multiarray plates as per manufacturer's instructions.

\section{Ambulatory electrocardiography (ECG) measurements}

Heart rate variability (HRV) and repolarization endpoints were measured using an ambulatory electrocardiographic monitor as described previously [22, 26]. Briefly, continuous ambulatory electrocardiograms (ECGs) were collected using a Mortara H12+12-Lead ECG Recorder (Mortara Instrument Co., Milwaukee, WI). Subjects rested in a quiet dark room for $20 \mathrm{~min}$ and Holter parameters were measured from the next 5 min. We calculated high frequency $(\mathrm{HF}, 0.15-0.4 \mathrm{~Hz})$, low frequency (LF, $0.04-0.15 \mathrm{~Hz})$ and total power $(0$ $0.4 \mathrm{~Hz}$ ) in absolute units (LF and HF components were normalized to account for changes in heart rate). Timedomain parameters measured included heart rate (min, max, mean), standard deviation of NN intervals (SDNN), and percentage of successive RR intervals that differ by more than $50 \mathrm{~ms}$ (pNN50). Cardiac repolarization endpoints measured included the duration of the QT interval, heart rate corrected QT (QTc), P-wave, QRS complex, and $\mathrm{T}$-wave. P-wave duration is a measure of atrial depolarization and contraction. QRS complex is a measure associated with ventricular depolarization. QTc 
is the interval where ventricles depolarize and repolarize. $\mathrm{T}$-wave is a measure of ventricular repolarization.

\section{Statistical analysis}

We assessed lung function, blood markers, and HRV measurements immediately before, $1 \mathrm{~h}$ after, and $20 \mathrm{~h}$ after each exposure. For the analysis, we normalized post-exposure and follow-up exposure values by the corresponding pre-exposure value and compared the percent point difference between filtered air exposure and $\mathrm{PM}_{2.5}$ exposure. Linear mixed effects models with random intercept for subject were used to measure differences in response between the filtered air and $\mathrm{PM}_{2.5}$ exposures ( $\mathrm{R}$ statistical software, version 3.6.2, package lme4) [27]. We used a subject level random intercept to account for the subject-level variability and estimated slope parameters to characterize the expected change in response as a function of $\mathrm{PM}_{2.5}$ concentration. Estimated slopes are presented as the percent point differences in normalized values $(95 \% \mathrm{CI})$ per $37.8 \mu \mathrm{g} / \mathrm{m}^{3}$ increase in $\mathrm{PM}_{2.5}$ exposure $\left(37.8 \mu \mathrm{g} / \mathrm{m}^{3}\right.$ corresponds to the mean concentration during $\mathrm{PM}_{2.5}$ exposures). Sex specific changes were not primary effects of interest and are reported here when significant. The study was powered based on primary endpoints that included forced expiratory volume in $1 \mathrm{~s}\left(\mathrm{FEV}_{1}\right)$, blood neutrophils, duration of the QT interval, and C-reactive protein (CRP). The power calculation based on the primary endpoints determined that 20 subjects was needed for adequate power (80\%). Statistical significance was determined at $p<0.05$.

\section{Results}

\section{Study population and $\mathrm{PM}_{2.5}$ exposure}

A total of 21 healthy subjects were recruited, and 20 (7 females and 13 males) completed the study. Most selfclassified as white $(n=14)$ and had a mean age of 25.3 years (Table 1, Table S1).

$\mathrm{PM}_{2.5}$ concentration in the chamber is measured on a continuous scale and varies from subject to subject depending on the outdoor PM concentration that day.

Table 1 Descriptive statistics of the study population $(n=20)$

\begin{tabular}{ll}
\hline Demographic variable Mean (+/- SD) & Mean (+/- SD) \\
\hline Sex (\%) & $65 \%$ \\
Male & $35 \%$ \\
Female & \\
Race (\%) & $70 \%$ \\
White & $20 \%$ \\
Black & $10 \%$ \\
Mixed (W/B) & $25.3 \pm 4.0$ \\
Age (years) & $25.5 \pm 3.6$ \\
BMl (kg/m²) &
\end{tabular}

Table 1 shows the average chamber concentrations during the filtered air and $\mathrm{PM}_{2.5}$ exposures. $\mathrm{PM}_{2.5}$ concentrations for filtered air and $\mathrm{PM}_{2.5}$ exposures averaged $2.2 \mu \mathrm{g} / \mathrm{m}^{3}$ (range: $-0.80-10.45 \mu \mathrm{g} / \mathrm{m}^{3}$ ) and $37.8 \mu \mathrm{g} / \mathrm{m}^{3}$ (range: $25.8-52.9 \mu \mathrm{g} / \mathrm{m}^{3}$ ), respectively (Table 2 ).

\section{Near ambient levels of $\mathbf{P M}_{2.5}$ decreased lung function}

Elevated $\mathrm{PM}_{2.5}$ was associated with decreased lung capacity and reduced pulmonary function. One hour after $\mathrm{PM}_{2.5}$ exposure, $\mathrm{FEV}_{1}$ and PEF were marginally decreased by $0.8 \%$ (95\%CI: $0.03-1.7 \%, p=0.054$ ) and $1.8 \%$ (95\%CI: $-0.1-$ $3.7 \%, p=0.077)$, respectively. $\mathrm{FEV}_{1} / \mathrm{FVC}$ was significantly decreased by $1.2 \%$ (95\%CI: $0.1-2.4 \%, p=0.048) 1 \mathrm{~h}$ postexposure (Fig. 1, Table 3, Table S2). Sex specific changes were observed with the decrease in $\mathrm{FEV}_{1} 1 \mathrm{~h}$ postexposure, where in males the $\mathrm{FEV}_{1}$ significantly decreased by $1.4 \%$ (95\%CI: $0.4-2.5 \%, p=0.02$ ) (Fig. 1 , Table 3 , Table S2). As expected, all lung function measures had returned to baseline by $20 \mathrm{~h}$ post-exposure.

\section{Near ambient levels of $\mathrm{PM}_{2.5}$ resulted in vascular inflammation and acute phase injury}

$\mathrm{PM}_{2.5}$ exposure was associated with increased serum levels of several inflammatory markers. Relative to filtered air, acute phase inflammation markers SAA and CRP were significantly increased $1 \mathrm{~h}$ after the average $\mathrm{PM}_{2.5}$ exposure by $8.7 \%$ (95\%CI: $1.3-16.1 \%, p=0.027$ ), 9.1\% (95\%CI: $1.0-17.2 \%, p=0.034)$, respectively. SAA and CRP were further elevated $20 \mathrm{~h}$ after exposure where SAA was $34.6 \%$ (95\%CI: $13.1-56.1 \%, p=0.004)$ higher and CRP was $22.8 \%(95 \% \mathrm{CI}:-2.9-48.7 \%, p=0.092)$ higher (marginal) than pre-exposure measurements. Additionally, relative to measures taken before exposure, percent neutrophils were decreased by $6.5 \%$ (95\%CI: $0.8-13.9 \%, p=0.091)$, although not significant, and significantly decreased by $5.7 \%$ (95\%CI: $0.6-11.1 \%, p=$ $0.040) 1 \mathrm{~h}$ and $20 \mathrm{~h}$ after $\mathrm{PM}_{2.5}$ exposure, respectively (Fig. 2, Table 3, Table S2).

An inflammatory response was also observed through increases in endpoints typically stimulated by inflammatory cytokines. Compared to filtered air, sICAM and sVCAM were significantly increased $1 \mathrm{~h}$ after the average $\mathrm{PM}_{2.5}$ exposure by $10.7 \%$ (95\%CI: $4.0-17.5 \%, p=0.003$ ) and $6.6 \%(95 \% \mathrm{CI}: 1.3-12.0 \%, p=0.022)$, respectively (Fig. 2, Table 3, Table S2). Among the inflammatory cytokines which are upstream of sICAM and sVCAM, we observed a $12.7 \%$ increase $(95 \% \mathrm{CI}$ : $-9.0-34.4 \%, p=0.26)$

Table 2 Average $\mathrm{PM}_{2.5}$ concentration ( \pm standard deviation) for clean air and concentrated $\mathrm{PM}_{2.5}$ exposures $\left(\mu \mathrm{g} / \mathrm{m}^{3}\right)$

\begin{tabular}{ll}
\hline Exposure Treatment & Mean $( \pm$ SD) \\
\hline Clean air & $2.1 \pm 2.6$ \\
Concentrated $\mathrm{PM}_{2.5}$ & $37.8 \pm 6.5$ \\
\hline
\end{tabular}




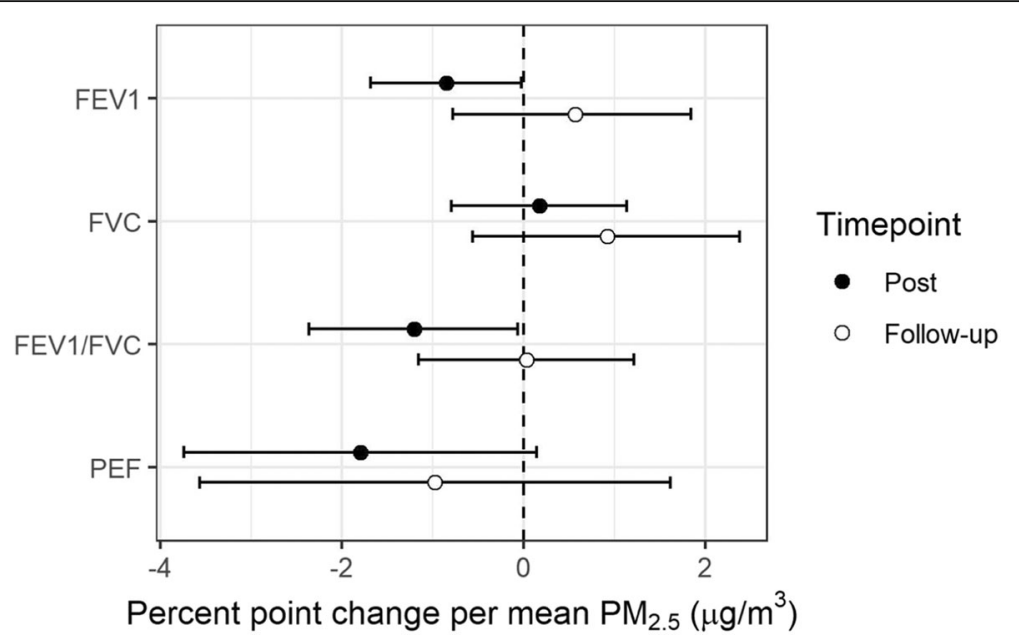

Fig. 1 Mean percent point change in lung function (95\%Cl): $1 \mathrm{~h}$ after exposure (Post) and approximately $20 \mathrm{~h}$ after exposure (Follow-up). Mean change is expressed per $37.8 \mathrm{\mu g} / \mathrm{m}^{3}$ of $\mathrm{PM}_{2.5}$, which corresponds to average concentrated $\mathrm{PM}_{2.5}$ exposure across subjects

in IL-6 $1 \mathrm{~h}$ after exposure. However, that change was not statistically significant. There were also no observed statistically significant changes in other inflammatory cytokines including IL-1b, IL-8, and TNF- $\alpha$ (Fig. 2, Table 3, Table S2).

\section{Near ambient levels of $\mathrm{PM}_{2.5}$ resulted in changes in HRV and cardiac repolarization}

No significant associations were observed between $\mathrm{PM}_{2.5}$ and the HRV time domain measurements SDNN and pNN50. When considering effects within strata by sex, SDNN increased by $23.9 \%$ (95\%CI: $8.6-41.1 \%, p=0.02$ ) in females and decreased by $26.2 \%$ (95\%CI: $1.9-50.6 \%$, $p=0.046$ ) in males $1 \mathrm{~h}$ after $\mathrm{PM}_{2.5}$ exposure. HRV frequency domain parameters (nHF, nLF, HF/LF) measured $1 \mathrm{~h}$ or $20 \mathrm{~h}$ post exposure did not have significant associations with $\mathrm{PM}_{2.5}$ (Fig. 3, Table 3, Table S2).

Cardiac repolarization measures including the duration of the P-wave, QRS complex, QT interval (QTc), and $\mathrm{T}$-wave were altered by $\mathrm{PM}_{2.5}$ exposure. P-wave duration increased by $10.5 \%$ (95\% CI: $4.0-$ $17.1 \%, p=0.005) 1 \mathrm{~h}$ post exposure and the QRS complex decreased marginally by $4.6 \%$ (95\%CI: $-0.7-$ $9.9 \%, p=0.095) 20 \mathrm{~h}$ post exposure to $\mathrm{PM}_{2.5}$. Changes in repolarization measures were more pronounced in men where $1 \mathrm{~h}$ after $\mathrm{PM}_{2.5}$ exposure the $\mathrm{P}$-wave and QRS complex, increased by $15.4 \%$ (95\%CI: $8.7-22.3 \%$, $p=0.001)$ and $5.4 \%(95 \% \mathrm{CI}: 1.0-9.5 \%, \mathrm{p}=0.02)$, respectively. QTc and T-wave measures did not change for the whole group, but in females QTc was decreased by $1.6 \%$ (95\%CI: $0.5-2.9 \%, p=0.03) 1 \mathrm{~h}$ after exposure and $\mathrm{T}$-wave was decreased by $17.4 \%$ (95\%CI: $6.9-27.6 \%, p=0.01$ ) $20 \mathrm{~h}$ after exposure (Fig. 3, Table 3, Table S2).
Near ambient levels of $\mathrm{PM}_{2.5}$ resulted in changes in markers of cell injury and red blood cell function

Elevated $\mathrm{PM}_{2.5}$ was associated with decreases in multiple cellular measures. LDH, a marker of cell injury was decreased by $6.9 \%(95 \% \mathrm{CI}: 0.5-13.3 \%, p=0.04) 1 \mathrm{~h}$ post and by $11.2 \%(95 \% \mathrm{CI}: 5.0-17.4 \%, \mathrm{p}=0.001) 20 \mathrm{~h}$ post. Percent hematocrit was 1.4\% (95\%CI: $0.01-2.9 \%, p=$ 0.058 ) lower (marginally) than pre-exposure measurements $20 \mathrm{~h}$ after $\mathrm{PM}_{2.5}$ exposure (Fig. 4, Table 3, Table S2). We did not observe significant changes in the other systemic blood or lipid markers measured (Table 3).

\section{Discussion}

This study is the first to provide direct evidence of detrimental health impacts related to short-term lowconcentration fine particulate matter exposure in healthy young volunteers. $\mathrm{PM}_{2.5}$ concentrations in this study were close to the daily US NAAQS standard and are applicable to a large proportion of the general US population. Over 75 million individuals reside in a county that exceeds the average $\mathrm{PM}_{2.5}$ concentration in this study for 1 day annually, and over 54 million reside in a county that exceeds this average for 7 or more days [28]. At $\mathrm{PM}_{2.5}$ concentrations near the daily US NAAQS, we found alterations in biomarkers of vascular injury, cardiac electrophysiology, and lung function, indicating that similar pathways appear to be altered at both high and low $\mathrm{PM}_{2.5}$ concentrations.

In healthy young adults exposed to low $\mathrm{PM}_{2.5}$ concentrations for $4 \mathrm{~h}$, we observed 7 to $11 \%$ increases in vascular inflammation markers, SAA, CRP, sICAM, and sVCAM, $1 \mathrm{~h}$ after exposure. One hour after exposure, we also observed 1 to $2 \%$ decreases in lung capacity $\left(\mathrm{FEV}_{1}\right.$ and PEF) and lung function $\left(\mathrm{FEV}_{1} /\right.$ 
Table 3 Changes in blood chemistry, cellular, HRV, inflammatory, lung function, and repolarization measures $(95 \% \mathrm{Cl}): 1 \mathrm{~h}$ after exposure (Post) and approximately $20 \mathrm{~h}$ after exposure (Follow-up). Mean change is expressed per $37.8 \mu \mathrm{g} / \mathrm{m}^{3}$ of PM 2.5 , which corresponds to average concentrated $\mathrm{PM}_{2.5}$ exposure across subjects

\begin{tabular}{|c|c|c|c|}
\hline Group & Endpoint & Post & Follow-up \\
\hline \multirow[t]{12}{*}{ Blood Chemistry } & Cholesterol (mg/dL) & $1.4(-3.0,5.9)$ & $0.6(-3.1,4.4)$ \\
\hline & $\mathrm{HDL}(\mathrm{mg} / \mathrm{dL})$ & $-0.4(-5.3,4.6)$ & $-1.4(-6.3,3.6)$ \\
\hline & LDL (mg/dL) & $5.5(-3.7,14.6)$ & $4.3(-1.9,10.8)$ \\
\hline & Triglycerides (mg/dL) & $-14.3(-40.5,13.3)$ & $-17.3(-41.2,6.6)$ \\
\hline & VLDL (mg/dL) & $-12.9(-38.4,13.9)$ & $-16.8(-41.2,7.6)$ \\
\hline & D-Dimer (ng/mL) & $10.7(-12.1,33)$ & $-4.4(-21.5,12.6)$ \\
\hline & LDH (IU/L) & $-6.9(-13.3,-0.5)$ & $-11.2(-17.4,-5.0)$ \\
\hline & PAl-1 (ng/mL) & $-1.2(-16.2,13.6)$ & $7.0(-15.9,29.3)$ \\
\hline & Plasminogen (\%) & $2.2(-5.1,9.6)$ & $1.7(-6.9,10.4)$ \\
\hline & Protein (g/dL) & $-0.2(-3.2,2.8)$ & $0.1(-1.9,2.2)$ \\
\hline & $\mathrm{tPA}(\mathrm{ng} / \mathrm{mL})$ & $3.9(-3.8,11.4)$ & $-3.5(-13.1,5.8)$ \\
\hline & VWF (\%) & $-6.9(-23.0,9.2)$ & $6.0(-7.5,19.5)$ \\
\hline \multirow[t]{10}{*}{ Cellular } & Basophils (\%) & $-3.6(-51.2,44.0)$ & $-0.4(-38.1,40.4)$ \\
\hline & Eosinophils ( $10^{3}$ cells/uL) & $-38.4(-146.2,70.8)$ & $-4.5(-19.6,11.5)$ \\
\hline & Eosinophils (\%) & $1.2(-15.8,18.3)$ & $2.1(-16.9,21.7)$ \\
\hline & Lymphocytes (\%) & $2.1(-3.5,7.7)$ & $6.3(-0.9,14.2)$ \\
\hline & Monocytes ( $10^{3}$ cells/uL) & $-2.2(-13.8,9.1)$ & $-2.6(-14.2,8.3)$ \\
\hline & Monocytes (\%) & $0.8(-11.1,12.3)$ & $2.9(-8.1,13.6)$ \\
\hline & Neutrophils (\%) & $-6.5(-13.9,0.8)$ & $-5.7(-11.1,-0.6)$ \\
\hline & Platelets ( $10^{3}$ cells/uL) & $-0.8(-6.3,4.8)$ & $-0.5(-4.7,3.8)$ \\
\hline & RBC $\left(10^{3}\right.$ cells/uL $)$ & $-0.5(-2.5,1.4)$ & $-1.6(-3.2,0.0)$ \\
\hline & WBC $\left(10^{3}\right.$ cells/uL $)$ & $3.3(-11.8,18.5)$ & $-4.8(-14.1,4.5)$ \\
\hline \multirow[t]{5}{*}{ HRV } & $H F / L F$ & $12.7(-17.4,42.7)$ & $17.0(-31.3,65.2)$ \\
\hline & $\mathrm{HFn}$ & $8.6(-6.4,23.7)$ & $13.0(-12.8,38.7)$ \\
\hline & LFn & $-0.7(-19.1,16.6)$ & $-13.3(-31.3,4.8)$ \\
\hline & pNN50 (\# of NN intervals) & $2.0(-33.8,38.0)$ & $154.5(-178.2,487.2)$ \\
\hline & SDNN (ms) & $-6.6(-25.2,12.0)$ & $10.6(-21.8,43.0)$ \\
\hline \multirow[t]{8}{*}{ Inflammatory } & CRP (ng/mL) & $9.1(1.0,17.2)$ & $22.8(-2.9,48.7)$ \\
\hline & IL-1b (pg/mL) & $-3.0(-14.7,8.7)$ & $1.9(-8.7,13.1)$ \\
\hline & IL-6 (pg/mL) & $12.7(-9,34.4)$ & $-3.0(-17.3,11.5)$ \\
\hline & IL-8 (pg/mL) & $-1.5(-9.9,7.0)$ & $0.8(-13.2,14.8)$ \\
\hline & sICAM (ng/mL) & $10.7(4 ., 17.5)$ & $6.5(-1.7,14.7)$ \\
\hline & $\mathrm{SAA}(\mathrm{ng} / \mathrm{mL})$ & $8.7(1.3,16.1)$ & $34.6(13.1,56.1)$ \\
\hline & sVCAM (ng/mL) & $6.6(1.3,12.0)$ & $2.5(-3.9,8.9)$ \\
\hline & TNF-a (pg/mL) & $-1.4(-6.1,3.3)$ & $0.2(-7.1,7.5)$ \\
\hline \multirow[t]{5}{*}{ Lung function } & FEF $25-75 \%$ & $-1.6(-4.3,1.1)$ & $0.6(-2.4,3.5)$ \\
\hline & $\mathrm{FEV}_{1}$ & $-0.8(-1.7,0.0)$ & $0.6(-0.8,1.8)$ \\
\hline & $\mathrm{FEV}_{1} / \mathrm{FVC}$ & $-1.2(-2.4,-0.1)$ & $0.0(-1.2,1.2)$ \\
\hline & FVC & $0.2(-0.8,1.1)$ & $0.9(-0.6,2.4)$ \\
\hline & PEF & $-1.8(-3.7,0.1)$ & $-1.0(-3.6,1.6)$ \\
\hline \multirow[t]{2}{*}{ Repolarization } & Max HR (beats per min) & $-3.3(-9.3,2.6)$ & $1.9(-6.5,10.2)$ \\
\hline & Mean HR (beats per min) & $-1.9(-8.6,4.5)$ & $-0.4(-6.2,5.5)$ \\
\hline
\end{tabular}


Table 3 Changes in blood chemistry, cellular, HRV, inflammatory, lung function, and repolarization measures $(95 \% \mathrm{Cl}): 1 \mathrm{~h}$ after exposure (Post) and approximately $20 \mathrm{~h}$ after exposure (Follow-up). Mean change is expressed per $37.8 \mu \mathrm{g} / \mathrm{m}^{3}$ of $\mathrm{PM}_{2.5}, \mathrm{which}$ corresponds to average concentrated $\mathrm{PM}_{2.5}$ exposure across subjects (Continued)

\begin{tabular}{llll}
\hline Group & Endpoint & Post & Follow-up \\
\hline Min HR (beats per min) & $-0.9(-9.3,7.6)$ & $-1.7(-9.7,6.2)$ & $-5.7(-20,8.7)$ \\
& P-wave (ms) & $10.5(4.0,17.1)$ & $-4.6(-9.9,0.7)$ \\
QRS complex (ms) & $2.2(-1.6,6.0)$ & $-0.1(-1.7,1.5)$ & $0.4(-2.2,3.1)$ \\
QT interval (ms) & $-0.3(-1.1,0.6)$ & $0.1(-1.6,1.7)$ \\
QTc interval (ms) & $-0.9(-9.7,7.9)$ & $-6.1(-13.2,1.2)$ \\
\hline
\end{tabular}

FVC). Additionally, neutrophils and lactase dehydrogenase were decreased $6-11 \%$ both $1 \mathrm{~h}$ and $20 \mathrm{~h}$ post exposure. To our knowledge, this is the first clinical study to examine repolarization measures at levels of $\mathrm{PM}_{2.5}$ near the current daily $\mathrm{PM}_{2.5}$ US NAAQS. Previous short-term controlled exposures to concentrated air particles were done at average concentrations ranging from 89 to $278 \mu \mathrm{g} / \mathrm{m}^{3}$. In models with all individuals, we observed changes in cardiac repolarization including a $10.5 \%$ increase in $\mathrm{P}$-wave $1 \mathrm{~h}$ after exposure, and a $4.6 \%$ decrease in QRS-wave $20 \mathrm{~h}$ after exposure. These changes were pronounced in models containing only males. Differences by sex were also observed with other cardiac repolarization and time domain measurements. In the female strata, QTc decreased by $1.6 \% 1 \mathrm{~h}$ after exposure and $\mathrm{T}$-wave decreased by $17.4 \% 20 \mathrm{~h}$ after exposure. With the time domain measurement, SDNN increased $23.9 \%$ in females and decreased $2.2 \%$ in male strata $1 \mathrm{~h}$ post. The reported results suggest that there could be impacts to depolarization and repolarization in some populations that could lead to arrhythmia. However, we cannot make strong conclusions regarding differences by sex due to the small sample size. Further research is necessary to examine potential sex related differences. Importantly, the cardiopulmonary effects

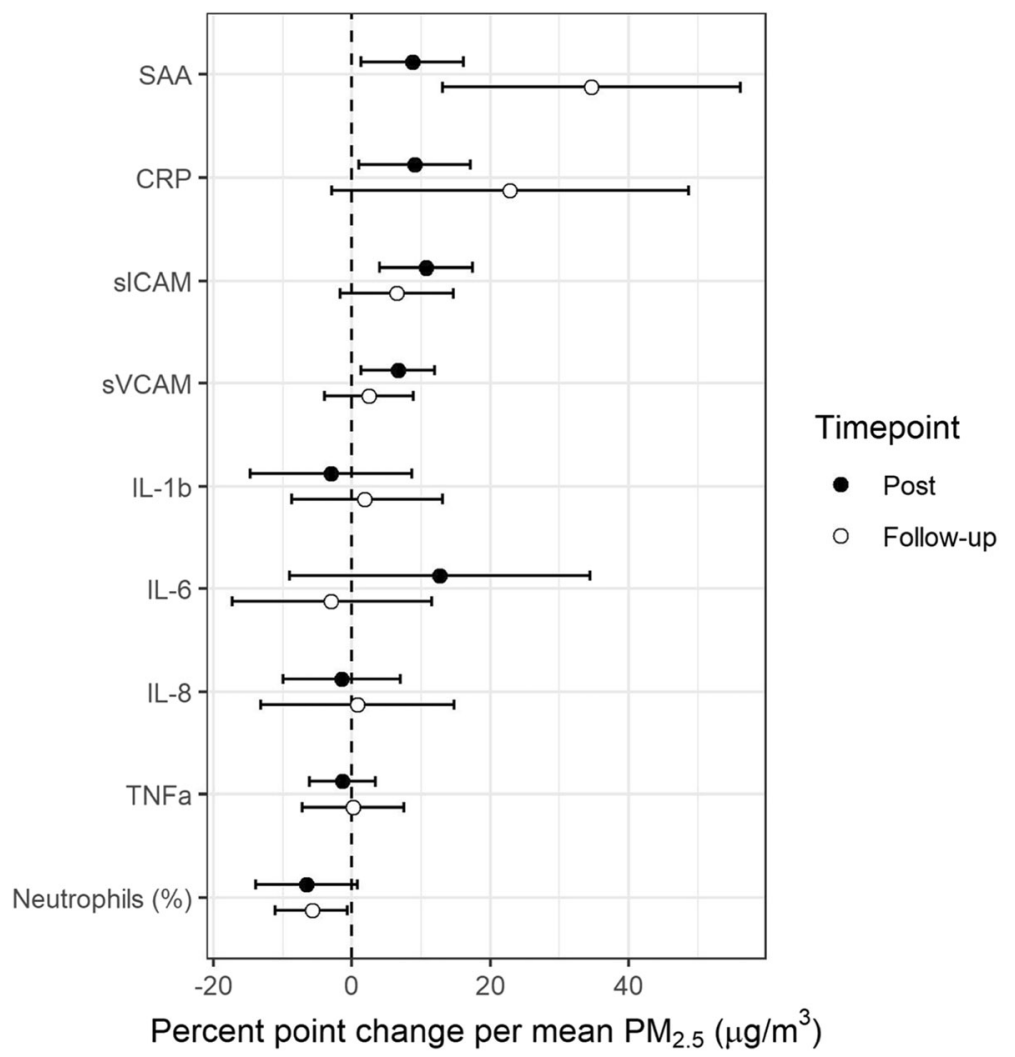

Fig. 2 Mean percent point change in systemic inflammation markers (95\%Cl): $1 \mathrm{~h}$ after exposure (Post) and approximately $20 \mathrm{~h}$ after exposure (Follow-up). Mean change is expressed per $37.8 \mu \mathrm{g} / \mathrm{m}^{3}$ of $\mathrm{PM}_{2.5}$, which corresponds to average concentrated $\mathrm{PM}_{2.5}$ exposure across subjects 


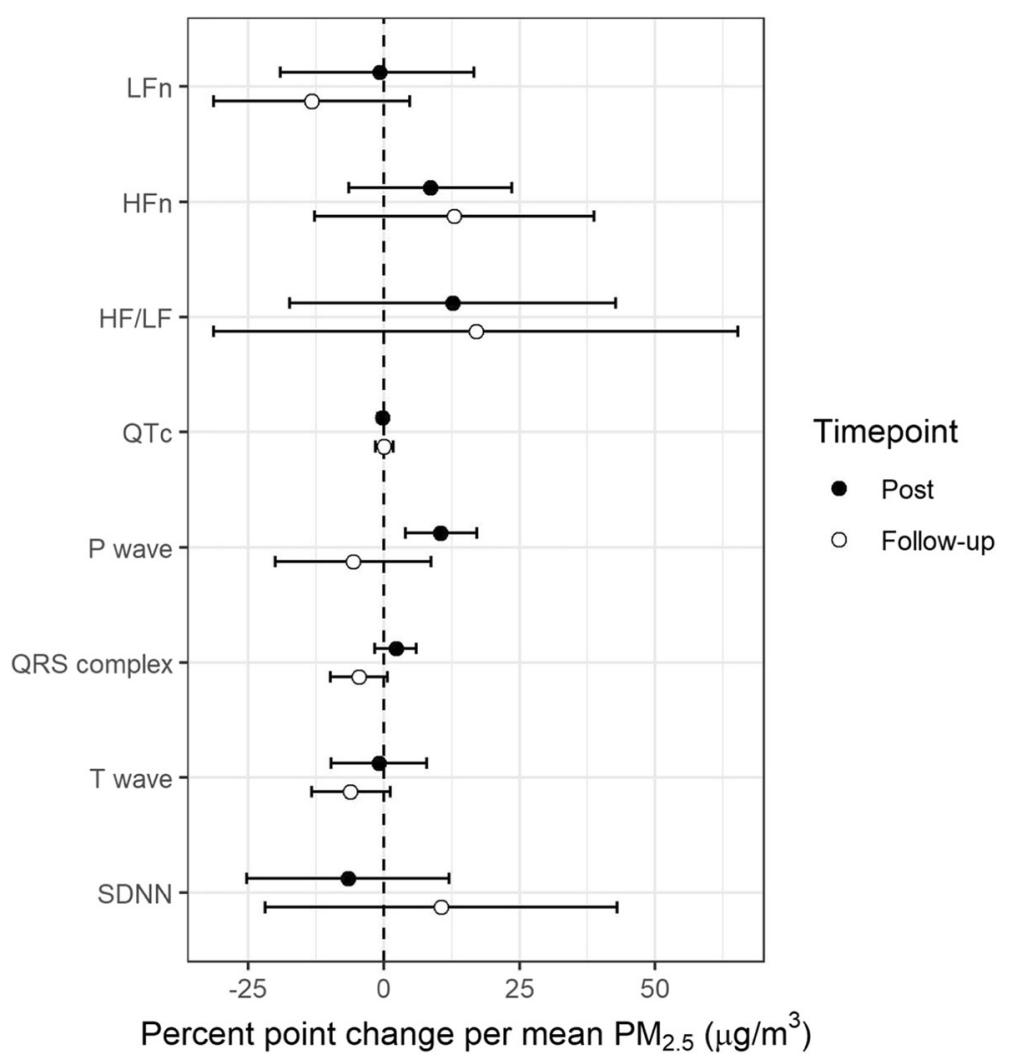

Fig. 3 Mean percent point change in HRV and cardiac repolarization measures ( $95 \% \mathrm{Cl}): 1 \mathrm{~h}$ after exposure (Post) and approximately $20 \mathrm{~h}$ after exposure (Follow-up). Mean change is expressed per $37.8 \mu \mathrm{g} / \mathrm{m}^{3}$ of $\mathrm{PM}_{2.5}$, which corresponds to average concentrated $\mathrm{PM}_{2.5}$ exposure across subjects

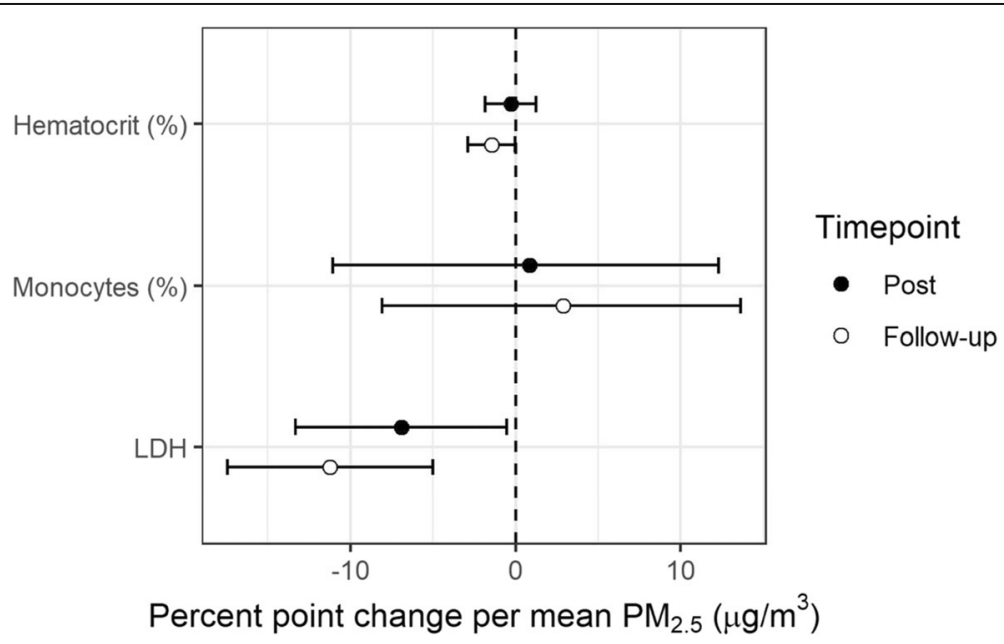

Fig. 4 Mean percent point change in blood chemistry and lipids measures $(95 \% \mathrm{Cl}): 1 \mathrm{~h}$ after exposure (Post) and approximately $20 \mathrm{~h}$ after exposure (Follow-up). Mean change is expressed per $37.8 \mu \mathrm{g} / \mathrm{m}^{3}$ of $\mathrm{PM}_{2.5}$, which corresponds to average concentrated $\mathrm{PM}_{2.5}$ exposure across subjects 
observed here are similar to studies with higher $\mathrm{PM}_{2.5}$ exposures, providing evidence that the pathways altered at high-dose exposures are also impacted at low-dose exposures.

Associations with a pro-inflammatory response have been observed previously in other clinical studies [13, 24, 25, 29-33]. In studies with a similar exposure design, this response has been observed through PM related increases in TNF- $\alpha$ [13], inflammatory proteins (CRP and SAA) [29], fibrinogen [25, 32], and plasminogen activator and endothelin-1 levels [33]. Evidence of systemic and localized inflammation has also been observed in laboratory studies through increases in cellular adhesion molecules in an in vitro study [34] and elevated TNF- $\alpha$ and IL-6 levels in lung tissue [35-38]. In this study, we evaluated effects of systematic inflammation from short term exposure, but did not observe significant associations with IL-6, IL-8, IL-1b, and TNF- $\alpha$; however, we did observe a trend with IL- 6 being elevated post exposure (13\%). Previously, IL-6 has been observed to be elevated with long-term $\mathrm{PM}_{2.5}$ exposures [39]. We also observed decreases in white blood cells following acute $\mathrm{PM}_{2.5}$ exposure, similar to another controlled human exposure study with healthy volunteers [40]. The observed decrease in neutrophils in these studies may reflect a movement of white blood cells from large vessels to smaller arteries and capillaries. Indeed, prior work has observed significant increases in neutrophils in lavage samples, suggesting localized inflammation in lung tissue $[25,31,32]$. A reduction in lactate dehydrogenase was also observed in this study and while we are not sure on the mechanism, a similar decrease was observed in prior work [40].

Evidence of lung function impairments in association with long-term $\mathrm{PM}_{2.5}$ levels has been observed in environmental studies, but not with acute exposures in clinical studies. Lung function changes were not observed in our previous study that utilized a $2 \mathrm{~h}$ exposure and we hypothesize that the differences in observations in the current study are due to the longer exposure time. To our knowledge, this is the first study to observe potential obstructive impacts, via a significant decrease in the $\mathrm{FEV}_{1} / \mathrm{FVC}$ ratio, following a short-term exposure to moderate levels of $\mathrm{PM}_{2.5}$. Decreases in lung capacity have also been observed previously in ecological studies of children [41, 42], asthmatic children [43], and adults [44-47] through reductions in forced expiratory volume in $1 \mathrm{~s}\left(\mathrm{FEV}_{1}\right)$, forced vital capacity (FVC), and peak expiratory flow (PEF). Our results were comparable to a previous study conducted in healthy adults that had higher ambient $\mathrm{PM}_{2.5}$ concentrations and considered interactions with temperature. At temperatures above $20{ }^{\circ} \mathrm{C}$, elevated $\mathrm{PM}_{2.5}$ was associated with a $1.5-1.9 \%$ decrease in $\mathrm{FEV}_{1}$ [46]. The percent change in $\mathrm{FEV}_{1}$ observed in this study was lower than the $5-8 \%$ decrease in $\mathrm{FEV}_{1}$ observed in an ecological study in children with asthma [43]. Acute decreases in lung capacity may result from airway inflammation related to reactive oxygen species activation of MAPK and NF- $\mathrm{kB}$ signaling pathways or from an exacerbated Th immune response [48, 49].

In addition to respiratory impacts, cardiovascular effects have been observed in prior research through changes in heart rate variability and cardiac repolarization measures $[13,22,24,31]$. PM associated changes to the frequency domain and repolarization measures have not been observed consistently in prior clinical studies. Studies reporting HRV differences have observed increased high and low frequency measures [24], a reduction in the highfrequency/low-frequency ratio [22], and a decreased SDNN [31]. In this study, HRV measures (HF, LF, HF/LF ratio, pNN50, SDNN) were not observed to be impacted. Additionally, no changes in ventricular depolarization (QRS complex) were observed in this study, similar to a previous study [29]. However, cardiac repolarization changes including ventricular repolarization have been observed in studies with controlled PM exposures through prolongation of the QT interval [22, 24, 29]. Exposures in clinical studies may be too brief to observe differences in HRV endpoints, as significant changes have been observed in environmental studies assessing associations with longterm exposures [50-52].

Physical activity has a well-established benefit to general and cardiovascular health [53, 54], but it can also increase personal exposure through elevated ventilation rates thus presenting a more complex relationship [55]. Although there is not a consensus on the extent that physical activity may moderate air pollution related health outcomes [56], previous studies have reported changes in lung function, inflammation, and HRV in association with the short-term effects of air pollution exposure in individuals undergoing physical activity $[18,55,57,58]$. In panel and cross-over studies, short-term exposure to traffic related air pollution, diesel, and ultrafine particles was associated with reduced lung function, observed through decreases in FEV1, FVC, and PEF and increased fraction of exhaled nitric oxide [12, $17,55,57,58]$ and altered HRV, observed through decreases in HF and QT interval [17, 18, 55, 59, 60]. There is also evidence for systemic and localized lung inflammation [58]. In current study, physical activity was used to standardize dose between subjects and was not evaluated as an effect modifying factor. In that context, our results suggest that low concentrations of $\mathrm{PM}_{2.5}$ may acutely increase inflammation and reduce lung function in healthy young adults undergoing moderate physical activity.

There are a number of reasons why we hypothesize effects were observed in this study. First, raised ventilation rate related to the moderate physical activity would deliver 
a greater dose to subjects. The target ventilation rate in this study was greater than prior studies where subjects were exposed at rest [23, 32]. Secondly, the exposure time employed was twice that of many prior studies using concentrated air particles [15, 22, 23, 32, 40]. The combination of a greater ventilation rate and longer exposure time would lend to a comparable $2 \mathrm{~h}$ exposure of approximately $2-4$ times $\left(75-150 \mu \mathrm{g} / \mathrm{m}^{3}\right)$, depending on study design. In this exposure range, inflammation, cardiac repolarization, and decreased pulmonary function have been observed in other chamber studies involving concentrated air particles $[15,22,23,32,40]$. Cardiopulmonary changes have also been observed in studies with similar exposure methods and ultrafine particles [31, 55, 61, 62]. Important to note that direct comparison with other types of air pollution like wood smoke and diesel are a challenge as these types of air pollution are chemically different.

This study also had some limitations. Outside of lung function and HRV, our observations for blood endpoints including inflammation and cellular changes were limited to systemic impacts and do not provide information on localized effects in certain tissues or organs. Additionally, exposure to air pollutants or other toxicants in the day(s) preceding the subject's visit to the facility could have impacted their response and were not specifically controlled for in this study. As this study was conducted with young, healthy adults it may not be generalizable to other populations. We recognize that the sample size combined with the number of secondary endpoints present a limitation and could lead to false positive observations by chance. Using the Bonferroni correction would lead to no significant findings. However, there were also strengths. The randomized crossover study design reduced the influence of confounding because subjects serve as their own control. Another strength was that by controlling a subject's ventilation rate, based on body surface area, subjects received approximately the same internal dose of $\mathrm{PM}_{2.5}$. Lastly, gaseous pollutants such as ozone and nitrogen dioxide or vapors from air toxics were removed during the concentration process unlike in observational studies where exposures are experienced simultaneously. As such, the observed effects could be attributed directly to $\mathrm{PM}_{2.5}$.

\section{Conclusion}

This study builds on previous clinical exposure research by assessing PM-related effects on cardiopulmonary endpoints in healthy young adults at low $\mathrm{PM}_{2.5}$ concentrations, near the current US NAAQS standard, whereas previous studies used concentrations in the range of 89 to $278 \mu \mathrm{g} / \mathrm{m}^{3}$. This is a major strength as observations would be directly attributed to PM exposures that are relevant to low-dose exposure, which occurs in many regions in the US. We observed changes in lung function, markers of systemic inflammation, and vascular injury. Data from this study suggests that low-level $\mathrm{PM}_{2.5}$ concentrations near the US NAAQS daily standard induce similar alterations in biomarkers of vascular injury and lung function in young healthy adults.

\section{Supplementary Information}

The online version contains supplementary material available at https://doi. org/10.1186/s12989-020-00389-5.

Additional file 1: Table S1. Subject level demographic and $\mathrm{PM}_{2.5}$ concentration data.

Additional file 2: Table S2. Mean percent point change and differences in inflammatory, HRV and cardiac repolarization, lung function, blood chemistry, and lipids measures (95\%Cl): $1 \mathrm{~h}$ after exposure (Post) and approximately $20 \mathrm{~h}$ after exposure (Follow-up). Mean change is expressed per $37.8 \mu \mathrm{g} / \mathrm{m}^{3}$ of $\mathrm{PM}_{2.5}$, which corresponds to average concentrated $\mathrm{PM}_{2.5}$ exposure across subjects. Table S3. Mean values for inflammatory, HRV and cardiac repolarization, lung function, blood chemistry, and lipids measures for air and PM $_{2.5}$ exposures: Pre-exposure, $1 \mathrm{~h}$ after exposure (Post) and approximately $20 \mathrm{~h}$ after exposure (Followup)

\section{Acknowledgements}

The authors thank Radhika Dhingra, Lisa Dailey, Joleen Soukup, Shirley Harder, and Claudia Salazar for technical support and Tracy Montilla and Julie Wood for nursing support.

\section{Disclosure}

This manuscript has been reviewed by the Center for Public Health and Environmental Assessment, United States Environmental Protection Agency and approved for publication. Approval does not signify that the contents necessarily reflect the views and policies of the Agency nor does mention of trade names or commercial products constitute endorsement or recommendation for use.

\section{Authors' contributions}

Conception and design: MWC, RBD, DDS. Acquisition of data: MWC, RBD. Analysis and interpretation of data: LHW, AGR, RBD, DDS. Drafting and revisions of the manuscript: $L H W, A G R, M W C, R B D, D D S$. All authors read and approved the final manuscript.

\section{Funding}

This research was funded by United States Environmental Protection Agency intramural funds.

\section{Availability of data and materials}

The datasets used and/or analyzed during the current study are available from the corresponding author on reasonable request.

\section{Ethics approval and consent to participate}

The study protocol and consent forms were approved by the University of North Carolina at Chapel Hill Institutional Review Board and the US Environmental Protection Agency Human Subjects Research Review Office. The study has been registered as a clinical trial (ClinicalTrials.gov \# NCT03232086).

\section{Consent for publication}

Not applicable.

Competing interests

The authors declare that they have no competing interests. 
Received: 28 May 2020 Accepted: 5 November 2020

Published online: 16 November 2020

\section{References}

1. Brook RD, Rajagopalan S, Pope CA 3rd, Brook JR, Bhatnagar A, Diez-Roux AV, et al. Particulate matter air pollution and cardiovascular disease: an update to the scientific statement from the American Heart Association. Circulation. 2010;121(21):2331-78.

2. Dockery DW, Pope CA, Xu X, Spengler JD, Ware JH, Fay ME, et al. An association between air pollution and mortality in six U.S. cities. N Engl J Med. 1993;329(24):1753-9.

3. Wang Y, Shi L, Lee M, Liu P, Di Q, Zanobetti A, et al. Long-term Exposure to PM2.5 and Mortality Among Older Adults in the Southeastern US. Epidemiology (Cambridge, Mass). 2017;28(2):207-14.

4. Weichenthal S, Villeneuve PJ, Burnett RT, van Donkelaar A, Martin RV, Jones $\mathrm{RR}$, et al. Long-term exposure to fine particulate matter: association with nonaccidental and cardiovascular mortality in the agricultural health study cohort. Environ Health Perspect. 2014;122(6):609-15.

5. Cohen AJ, Brauer M, Burnett R, Anderson HR, Frostad J, Estep K, et al. Estimates and 25-year trends of the global burden of disease attributable to ambient air pollution: an analysis of data from the Global Burden of Diseases Study 2015. Lancet (London, England). 2017;389(10082):1907-18.

6. Dominici F, Peng RD, Bell ML, Pham L, McDermott A, Zeger SL, et al. Fine particulate air pollution and hospital admission for cardiovascular and respiratory diseases. Jama. 2006;295(10):1127-34.

7. Schwartz J, Dockery DW, Neas LM. Is Daily Mortality Associated Specifically with Fine Particles? J Air Waste Manag Assoc. 1996;46(10):927-39.

8. Bell ML, Ebisu K, Peng RD, Samet JM, Dominici F. Hospital admissions and chemical composition of fine particle air pollution. Am J Respir Crit Care Med. 2009;179(12):1115-20.

9. Di Q, Dai L, Wang Y, Zanobetti A, Choirat C, Schwartz JD, et al. Association of Short-term Exposure to air pollution with mortality in older AdultsAssociation of short-term exposure to air pollution with mortality in older AdultsAssociation of short-term exposure to air pollution with mortality in older adults. JAMA. 2017;318(24):2446-56.

10. Krall JR, Anderson GB, Dominici F, Bell ML, Peng RD. Short-term exposure to particulate matter constituents and mortality in a national study of U.S. urban communities. Environ Health Perspect. 2013;121(10):1148-53.

11. USEPA USEPA. Integrated science assessment (ISA) for particulate matter. 2009.

12. Matt F, Cole-Hunter T, Donaire-Gonzalez D, Kubesch N, Martínez D, Carrasco-Turigas $\mathrm{G}$, et al. Acute respiratory response to traffic-related air pollution during physical activity performance. Environ Int. 2016;97:45-55.

13. Brook RD, Urch B, Dvonch JT, Bard RL, Speck M, Keeler G, et al. Insights into the mechanisms and mediators of the effects of air pollution exposure on blood pressure and vascular function in healthy humans. Hypertension. 2009:54(3):659-67.

14. Shah AP, Pietropaoli AP, Frasier LM, Speers DM, Chalupa DC, Delehanty JM, et al. Effect of inhaled carbon ultrafine particles on reactive hyperemia in healthy human subjects. Environ Health Perspect. 2008;116(3):375-80.

15. Gong H, Linn WS, Terrell SL, Anderson KR, Clark KW, Sioutas C, et al. Exposures of elderly volunteers with and without chronic obstructive pulmonary disease (COPD) to concentrated ambient fine particulate pollution. Inhal Toxicol. 2004;16(11-12):731-44.

16. Breitner S, Peters A, Zareba W, Hampel R, Oakes D, Wiltshire J, et al. Ambient and controlled exposures to particulate air pollution and acute changes in heart rate variability and repolarization. Sci Rep. 2019;9(1):1946.

17. Laeremans M, Dons E, Avila-Palencia I, Carrasco-Turigas G, Orjuela JP, Anaya E, et al. Short-term effects of physical activity, air pollution and their interaction on the cardiovascular and respiratory system. Environ Int. 2018:117:82-90.

18. Cole-Hunter T, Weichenthal S, Kubesch N, Foraster M, Carrasco-Turigas G, Bouso $L$, et al. Impact of traffic-related air pollution on acute changes in cardiac autonomic modulation during rest and physical activity: a cross-over study. J Expo Sci Environ Epidemiol. 2016;26(2):133-40.

19. Tanaka H, Monahan KD, Seals DR. Age-predicted maximal heart rate revisited. J Am Coll Cardiol. 2001;37(1):153-6.

20. Hankinson JL, Odencrantz JR, Fedan KB. Spirometric reference values from a sample of the general U.S. population. Am J Respir Crit Care Med. 1999; 159(1):179-87.

21. Madden MC, Stevens T, Case M, Schmitt M, Diaz-Sanchez D, Bassett M, et al. Diesel exhaust modulates ozone-induced lung function decrements in healthy human volunteers. Part Fibre Toxicol. 2014;11:37.
22. Tong H, Rappold AG, Diaz-Sanchez D, Steck SE, Berntsen J, Cascio WE, et al. Omega-3 fatty acid supplementation appears to attenuate particulate air pollution-induced cardiac effects and lipid changes in healthy middle-aged adults. Environ Health Perspect. 2012;120(7):952-7.

23. Devlin RB, Ghio AJ, Kehrl H, Sanders G, Cascio W. Elderly humans exposed to concentrated air pollution particles have decreased heart rate variability. Eur Respir J Suppl. 2003;40:76s-80s.

24. Samet JM, Rappold A, Graff D, Cascio WE, Berntsen JH, Huang YC, et al. Concentrated ambient ultrafine particle exposure induces cardiac changes in young healthy volunteers. Am J Respir Crit Care Med. 2009;179(11):1034-42.

25. Ghio AJ, Kim C, Devlin RB. Concentrated ambient air particles induce mild pulmonary inflammation in healthy human volunteers. Am J Respir Crit Care Med. 2000:162(3 Pt 1):981-8.

26. Tong H, Rappold AG, Caughey M, Hinderliter AL, Graff DW, Berntsen JH, et al. Cardiovascular effects caused by increasing concentrations of diesel exhaust in middle-aged healthy GSTM1 null human volunteers. Inhal Toxicol. 2014;26(6):319-26.

27. R Core Team. A language and environment for statistical computing. Vienna: R Foundation for Statistical Computing: 2019.

28. USEPA UEPA. Air quality system data Mart [internet database]. 2018.

29. Devlin RB, Smith CB, Schmitt MT, Rappold AG, Hinderliter A, Graff D, et al. Controlled exposure of humans with metabolic syndrome to concentrated ultrafine ambient particulate matter causes cardiovascular effects. Toxicol Sci. 2014;140(1):61-72

30. Ghio AJ, Soukup JM, Case M, Dailey LA, Richards J, Berntsen J, et al. Exposure to wood smoke particles produces inflammation in healthy volunteers. Occup Environ Med. 2012;69(3):170-5.

31. Graff DW, Cascio WE, Rappold A, Zhou H, Huang YC, Devlin RB. Exposure to concentrated coarse air pollution particles causes mild cardiopulmonary effects in healthy young adults. Environ Health Perspect. 2009;117(7):1089-94.

32. Holgate ST, Devlin RB, Wilson SJ, Frew AJ. Health effects of acute exposure to air pollution. Part II: Healthy subjects exposed to concentrated ambient particles. Res Rep Health Eff Inst. 2003;(112):31-50 discussion 1-67.

33. Tong H, Rappold AG, Caughey M, Hinderliter AL, Bassett M, Montilla T, et al. Dietary supplementation with olive oil or fish oil and vascular effects of concentrated ambient particulate matter exposure in human volunteers. Environ Health Perspect. 2015;123(11):1173-9.

34. Montiel-Davalos A, Alfaro-Moreno E, Lopez-Marure R. PM2.5 and PM10 induce the expression of adhesion molecules and the adhesion of monocytic cells to human umbilical vein endothelial cells. Inhal Toxicol. 2007;19(Suppl 1):91-8.

35. Davel AP, Lemos M, Pastro LM, Pedro SC, de Andre PA, Hebeda C, et al. Endothelial dysfunction in the pulmonary artery induced by concentrated fine particulate matter exposure is associated with local but not systemic inflammation. Toxicology. 2012;295(1-3):39-46.

36. Duan Z, Du FY, Yuan YD, Zhang YP, Yang HS, Pan WS. Effects of PM2.5 exposure on Klebsiella pneumoniae clearance in the lungs of rats. Zhonghua Jie He He Hu Xi Za Zhi. 2013;36(11):836-40.

37. Riva DR, Magalhães CB, Lopes AA, Lanças T, Mauad T, Malm O, et al. Low dose of fine particulate matter (PM2.5) can induce acute oxidative stress, inflammation and pulmonary impairment in healthy mice. Inhal Toxicol. 2011;23(5):257-67.

38. Wang G, Zhen L, Lu P, Jiang R, Song W. Effects of ozone and fine particulate matter (PM2.5) on rat cardiac autonomic nervous system and systemic inflammation. Wei Sheng Yan Jiu. 2013;42(4):554-60.

39. Hajat A, Allison M, Diez-Roux AV, Jenny NS, Jorgensen NW, Szpiro AA, et al. Long-term Exposure to Air Pollution and Markers of Inflammation, Coagulation, and Endothelial Activation A Repeat-measures Analysis in the Multi-Ethnic Study of Atherosclerosis (MESA). Epidemiology. 2015;26(3):310-20.

40. Ghio AJ, Hall A, Bassett MA, Cascio WE, Devlin RB. Exposure to concentrated ambient air particles alters hematologic indices in humans. Inhal Toxicol. 2003;15(14):1465-78.

41. Jacobson Lda S, Hacon Sde S, Castro HA, Ignotti E, Artaxo P. Ponce de Leon AC. Association between fine particulate matter and the peak expiratory flow of schoolchildren in the Brazilian subequatorial Amazon: a panel study. Environ Res. 2012;117:27-35.

42. Rice MB, Rifas-Shiman SL, Litonjua AA, Oken E, Gillman MW, Kloog I, et al. Lifetime exposure to ambient pollution and lung function in children. Am J Respir Crit Care Med 2016;193(8):881-8.

43. Loftus C, Yost M, Sampson P, Arias G, Torres E, Vasquez VB, et al. Regional PM2.5 and asthma morbidity in an agricultural community: a panel study. Environ Res. 2015;136:505-12. 
44. Thaller El, Petronella SA, Hochman D, Howard S, Chhikara RS, Brooks EG Moderate increases in ambient PM2.5 and ozone are associated with lung function decreases in beach lifeguards. J Occup Environ Med. 2008:50(2): 202-11.

45. Wu S, Deng F, Hao Y, Shima M, Wang X, Zheng C, et al. Chemical constituents of fine particulate air pollution and pulmonary function in healthy adults: the healthy volunteer natural relocation study. J Hazard Mater. 2013;260:183-91.

46. Wu S, Deng F, Hao Y, Wang X, Zheng C, Lv H, et al. Fine particulate matter, temperature, and lung function in healthy adults: findings from the HVNR study. Chemosphere. 2014;108:168-74.

47. Edginton S, O'Sullivan DE, King W, Lougheed MD. Effect of outdoor particulate air pollution on FEV1 in healthy adults: a systematic review and meta-analysis. Occup Environ Med. 2019.

48. Wang $H$, Song $L$, Ju W, Wang $X$, Dong L, Zhang Y, et al. The acute airway inflammation induced by PM2.5 exposure and the treatment of essential oils in Balb/c mice. Sci Rep. 2017:7(1):44256.

49. Wang J, Huang J, Wang L, Chen C, Yang D, Jin M, et al. Urban particulate matter triggers lung inflammation via the ROS-MAPK-NF-KB signaling pathway. J Thorac Dis. 2017;9(11):4398-412.

50. He F, Shaffer ML, Li X, Rodriguez-Colon S, Wolbrette DL, Williams R, et al. Individual-level $\mathrm{PM}_{2.5}$ exposure and the time course of impaired heart rate variability: the APACR study. J Expo Sci Environ Epidemiol. 2011;21(1):65-73.

51. Pope CA 3rd, Hansen ML, Long RW, Nielsen KR, Eatough NL, Wilson WE, et al. Ambient particulate air pollution, heart rate variability, and blood markers of inflammation in a panel of elderly subjects. Environ Health Perspect. 2004;112(3):339-45.

52. Tsai TY, Lo LW, Liu SH, Cheng WH, Chou YH, Lin WL, et al. Diurnal cardiac sympathetic hyperactivity after exposure to acute particulate matter 2.5 air pollution. J Electrocardiol. 2019;52:112-6.

53. Kohl HW 3rd. Physical activity and cardiovascular disease: evidence for a dose response. Med Sci Sports Exerc. 2001;33(6 Suppl):S472-83 discussion s93-4.

54. Warburton DE, Nicol CW, Bredin SS. Health benefits of physical activity: the evidence. CMAJ. 2006;174(6):801-9.

55. Frampton MW, Utell MJ, Zareba W, Oberdörster G, Cox C, Huang LS, et al. Effects of exposure to ultrafine carbon particles in healthy subjects and subjects with asthma. Res Rep. 2004;126:1-47 discussion 9-63.

56. DeFlorio-Barker S, Lobdell DT, Stone SL, Boehmer T, Rappazzo KM. Acute effects of short-term exposure to air pollution while being physically active, the potential for modification: a review of the literature. Prev Med. 2020;139: 106195.

57. Giles LV, Brandenburg JP, Carlsten C, Koehle MS. Physiological responses to diesel exhaust exposure are modified by cycling intensity. Med Sci Sports Exerc. 2014;46(10):1999-2006.

58. Kubesch NJ, de Nazelle A, Westerdahl D, Martinez D, Carrasco-Turigas G, Bouso $L$, et al. Respiratory and inflammatory responses to short-term exposure to traffic-related air pollution with and without moderate physical activity. Occup Environ Med. 2015;72(4):284-93.

59. Giles LV, Carlsten C, Koehle MS. The pulmonary and autonomic effects of high-intensity and low-intensity exercise in diesel exhaust. Environ Health. 2018;17(1):87.

60. Zareba W, Couderc JP, Oberdörster G, Chalupa D, Cox C, Huang LS, et al. ECG parameters and exposure to carbon ultrafine particles in young healthy subjects. Inhal Toxicol. 2009;21(3):223-33.

61. Gong H, Linn WS, Sioutas C, Terrell SL, Clark KW, Anderson KR, et al. Controlled exposures of healthy and asthmatic volunteers to concentrated ambient fine particles in Los Angeles. Inhal Toxicol. 2003;15(4):305-25.

62. Pietropaoli AP, Frampton MW, Hyde RW, Morrow PE, Oberdörster G, Cox C, et al. Pulmonary Function, Diffusing Capacity, and Inflammation in Healthy and Asthmatic Subjects Exposed to Ultrafine Particles. Inhal Toxicol. 2004; 16(sup1):59-72.

\section{Publisher's Note}

Springer Nature remains neutral with regard to jurisdictional claims in published maps and institutional affiliations.

\section{Ready to submit your research? Choose BMC and benefit from}

- fast, convenient online submission

- thorough peer review by experienced researchers in your field

- rapid publication on acceptance

- support for research data, including large and complex data types

- gold Open Access which fosters wider collaboration and increased citations

- maximum visibility for your research: over $100 \mathrm{M}$ website views per year

At BMC, research is always in progress.

Learn more biomedcentral.com/submissions 